\title{
GMR
}

\section{Genotype $x$ environment interaction on experimental hybrids of chili pepper}

\author{
N.S.S. Cabral ${ }^{1}$, A.M. Medeiros ${ }^{2}$, L.G. Neves ${ }^{1}$, C.P. Sudré2 ${ }^{2}$ S. Pimenta ${ }^{2}$, \\ V.J. Coelho ${ }^{1}$, M.E. Serafim ${ }^{3}$ and R. Rodrigues ${ }^{2}$ \\ ${ }^{1}$ Departamento de Agronomia, \\ Universidade do Estado de Mato Grosso, Cáceres, MT, Brasil \\ ${ }^{2}$ Laboratório de Melhoramento Genético Vegetal, \\ Universidade Estadual do Norte Fluminense Darcy Ribeiro, \\ Campos dos Goytacazes, RJ, Brasil \\ ${ }^{3}$ Departamento de Agronomia, Instituto Federal de Educação, \\ Ciência e Tecnologia de Mato Grosso, Cáceres, MT, Brasil \\ Corresponding author: R. Rodrigues \\ E-mail: rosana@uenf.br
}

Genet. Mol. Res. 16 (2): gmr16029551

Received November 23, 2016

Accepted February 20, 2017

Published April 20, 2017

DOI http://dx.doi.org/10.4238/gmr16029551

Copyright $(C 2017$ The Authors. This is an open-access article distributed under the terms of the Creative Commons Attribution ShareAlike (CC BY-SA) 4.0 License.

\begin{abstract}
In Brazil, cultivation of hybrid plants comprise near $40 \%$ of the area grown with vegetables. For Capsicum, hybrids of bell and chili peppers have already exceeded $50 \%$ and over $25 \%$ of all are commercialized seeds. This study aimed to evaluate new pepper hybrids in two environments, Cáceres, MT, and Campos dos Goytacazes, RJ, Brazil. Nine experimental hybrids of $C$. baccatum var. pendulum were tested and trials were performed in a randomized block design, with three replications and eight plants per plot. In each environment, plants were assessed for canopy diameter, plant height, number of fruit per plant, mean fruit mass per plant, fruit length and diameter, pulp thickness, and content of soluble solids. Seven of the eight traits have differed significantly due to environment variation. Furthermore, genotype and environment interaction was highly significant for number of fruit
\end{abstract}

Genetics and Molecular Research 16 (2): gmr16029551 
per plant, mean fruit mass per plant, fruit length, and fruit diameter. Choosing a hybrid to be grown in one of the studied locations must be in accordance with the sought characteristics since there is a complex interaction for some studied traits.

Key words: Capsicum baccatum var. pendulum; Vegetable breeding; New cultivars; Chili production

\section{INTRODUCTION}

The increased commercial interest in chili pepper fruit for fresh consumption or industrial and ornamental purposes has brought together a high demand for new chili pepper varieties combining high yield, food industry profitability, as well as aesthetic attractiveness. The Capsicum baccatum var. pendulum has been highlighted in production of sauces and spices as Calabrian pepper, whose preparation consists of seed dehydration and flocking (Madail et al., 2005; Carvalho et al., 2009). Until 2011, few researches on breeding of $C$. baccatum var. pendulum were found in specialized literature compared to bell pepper $(C$. annuиm var. annuит). However, being aware of this reality, researchers have intensified efforts on studies with peppers of the species C. baccatum. Among them, there are studies on phenotypic diversity characterization (Rêgo et al., 2011, 2015; Leite et al., 2016), diallelic analysis and correlation between quantitative traits (Gonçalves et al., 2011; Rodrigues et al., 2012; Medeiros et al., 2014; Rêgo et al., 2009, 2015), inheritance of resistance to Pepper yellow mosaic virus - PepYMV (Bento et al., 2013), new cultivars resistant to PepYMV (Oliveira et al., 2015), reference map building (Moulin et al., 2015b), and dissection of QTLs for agronomic traits (Moulin et al., 2015a).

A survey conducted in 2015 in seed-trading companies of Capsicum in Brazil found that at least 54 and $26 \%$ of bell and chili pepper cultivars marketed in the country are hybrids, respectively. This trend reflects a shift in preference of pepper producers, who are increasingly demanding as to productivity, quality and uniformity of fruit production, as well as disease resistance, which are present in commercial hybrids derived from a favorable heterotic effect on the expression of these traits (Nascimento et al., 2004; Charlo et al., 2011). Favorable heterotic effects have been observed in Capsicum for agronomic and productivity traits (Butcher et al., 2013; Singh et al., 2014). Bhutia et al. (2015) observed positive heterosis for yield per plant and content of carotenoids, vitamin $\mathrm{C}$, and capsaicin.

The response of a plant variety is distinct for each soil type, photoperiod, temperature, and irrigation management; this variation is called genotype $\mathrm{x}$ environment interaction (GxE) (Cruz et al., 2012). In genetic terms, this interaction occurs when genes controlling certain trait or the level of gene expression thereof differ among diverse environments. Such interaction makes the work of plant breeders more difficult, mainly when recommending superior genotypes by launching new cultivars. Nonetheless, as a biological phenomenon, it must be studied to the understanding of its nature (simple or complex) and contribution level, aiming to make a suitable recommendation of the best cultivars for each environment (Cruz and Castoldi, 1991; Ramalho et al., 2012).

This study reports the results of intermediate trials on interactions between experimental hybrids of C. baccatum var. pendulum in two environments, Cáceres, MT, and Campos dos Goytacazes, RJ, Brazil, by means of uni- and multivariate analyses.

Genetics and Molecular Research 16 (2): gmr16029551 


\section{MATERIAL AND METHODS}

\section{Plant material}

Nine hybrids bred by the Capsicum Breeding Program of the Universidade Estadual do Norte Fluminense Darcy Ribeiro (UENF) were assessed. Gonçalves et al. (2011) developed these hybrids from five parents (Table 1) in a complete diallel design without reciprocal crosses.

Table 1. Identification, morphological characteristics, and resistance to Pepper yellow mosaic virus (PepYMV)
of five accessions of Capsicum baccatum var. pendulum (Campos dos Goytacazes, Brazil).
\begin{tabular}{|l|l|l|l|c}
\hline Identification & Growth habit & Fruit color at maturity & Fruit shape & Resistance to PepYMV \\
\hline UENF 1616 & Intermediate & Orange & Elongate & S \\
\hline UENF 1624 & Erect & Red & Elongate & R \\
\hline UENF 1629 & Intermediate & Red & Elongate & Campanulate \\
\hline UENF 1639 & Intermediate & Red & Campanulate & S \\
\hline UENF 1732 & Intermediate & Red & R
\end{tabular}

Source: Bento et al. $(2007,2009)$. $\mathrm{R}=$ resistance; $\mathrm{S}=$ susceptibility.

\section{Morphoagronomical characterization}

The experiments were conducted in two distinct environments. The first, environment I, in the Unidade de Apoio à Pesquisa - UAP of the UENF, in Campos dos Goytacazes, northern Rio de Janeiro State, from March to October 2011. The other experiment, environment II, was carried out at an experimental unit of the Universidade Estadual de Mato Grosso - UNEMAT, in Cáceres, from June of 2012 to March 2013.

Both trials were conducted in an experimental design of randomized blocks with three replications, differing only by treatment randomization. The plots were composed of eight plants distributed in four plants per row. The spacing between rows and between plants within a row was 1.2 and $1.0 \mathrm{~m}$, respectively.

Seedlings were obtained after sowing the genotypes in 128-cell polystyrene trays using commercial organic substrate $\left(V_{i v a t t o}{ }^{\circledR}\right)$. Each cell received three seeds, being later thinned out to one seedling per cell. By reaching two pairs of true leaves, the seedlings were transplanted to the field. Fertilizations were made based on soil analysis and the other cultural practices such as hoeing, staking, and irrigation management were carried out according to crop management recommendations (Filgueira, 2012).

The following traits were evaluated: a) plant height $(\mathrm{PH})$ - measured to the highest part of plant in $\mathrm{cm}$, when $50 \%$ of the plot plants had ripe fruit; b) canopy diameter (CD) measured at the largest portion of the canopy in $\mathrm{cm}$, when $50 \%$ of the plot plants had ripe fruit; c) number of fruit per plant (NFP) - sum of number of fruit of all samples taken from one plant; d) mean fruit mass per plant (MFM) - ratio between the total mass of fruit per plant and the number of fruit per plant; e) fruit length (FL) - longer fruit length, in mm, of ripe fruit, taken by the average of ten fruit per plant of each plot; f) fruit diameter (DIAM) - wider fruit diameter, in $\mathrm{mm}$, taken by the average of ten fruit per plant of each plot; g) pulp thickness (PTH) - measured in ripe fruit, in mm, taken by the average of ten fruit per plant of each plot; h) soluble solid content (SSC) - in ${ }^{\circ}$ Brix, using a digital refractometer, taking an average of five fruit from four plants of each plot.

Genetics and Molecular Research 16 (2): gmr16029551 


\section{Data analysis}

The variables analyzed throughout the six harvests underwent an individual variance analysis and homogeneity was tested by maximum F statistics. Thereafter, a joint analysis of variance was performed followed by breakdown of interaction into simple and complex parts, using the method of Cruz and Castoldi (1991). Finally, the Scott-Knott clustering test (1974) was applied to each individual characteristic. All these analyses were performed using the Gene software (Cruz, 2013).

The UPGMA method was used to acquire a better understanding of the GxE interaction and clustering was based on standardized mean Euclidean distance. The data were analyzed by Genes (Cruz, 2013) and R (www.r-project.org) softwares, using the dendextend package.

\section{RESULTS AND DISCUSSION}

Considering the maximum F-test, the ratios between the higher and the lower experimental error variance were 1.20 for $\mathrm{PH}$ and 6.10 for MFM, allowing thus data joint analysis. The CV values (\%) for MFM, FL, DIAM, and PTH were low according to a pepper classification proposed by Silva et al. (2011). For all assessed traits, CV values ranged from $5.49 \%$ for DIAM to $21.75 \%$ for NFP (Table 2). Rodrigues et al. (2012) observed a variation between $2.06 \%$ for days to flowering up to $23.90 \%$ for productivity. These results ensure the accuracy of our findings.

Table 2. Means squares from combined ANOVA for eight quantitative traits related to plant and fruit of hybrids of Capsicum baccatum var. pendulum (Campos dos Goytacazes, Brazil).

\begin{tabular}{|c|c|c|c|c|c|c|c|c|c|}
\hline \multirow[t]{2}{*}{ Sources of variation } & \multicolumn{9}{|c|}{ Means squares } \\
\hline & d.f. & $\mathrm{CD}$ & $\mathrm{PH}$ & NFP & MFM & FL & DIAM & PTH & $\mathrm{SSC}$ \\
\hline Blocks/ Environment (E) & 4 & 233.1 & 371.9 & $18,129.7$ & 21.9 & 145.5 & 11.1 & 0.1 & 1.7 \\
\hline Hybrids $(\mathrm{H})$ & 8 & $299.2^{*}$ & $185.1^{*}$ & $73,672.1^{* *}$ & $166.2^{* *}$ & $1,843.7^{* *}$ & $473.6^{* *}$ & $0.4^{* *}$ & $1.9^{* *}$ \\
\hline E & 1 & $4,137.8^{*}$ & $2,610.8^{\mathrm{ns}}$ & $203,889.6^{* *}$ & $1,965.3 * *$ & $10,173.4^{* *}$ & $1,259.2 * *$ & $0.3^{\text {ns }}$ & $51.0 * *$ \\
\hline $\mathrm{H} \times \mathrm{E}$ & 8 & $108.3^{\text {ns }}$ & $61.3^{\mathrm{ns}}$ & $22,361.5^{* *}$ & $75.9 * *$ & $422.7^{* *}$ & $32.2 * *$ & $0.01^{\mathrm{ns}}$ & $0.7^{\mathrm{ns}}$ \\
\hline Mean & & 107.3 & 88 & 368.4 & 15.2 & 75.1 & 30.8 & 2.5 & 9.1 \\
\hline $\mathrm{CV}$ & & 9.5 & 9.6 & 21.8 & 11.6 & 7.0 & 5.5 & 7.9 & 7.8 \\
\hline MS/MS & & 1.4 & 1.2 & 6.1 & 6.1 & 2.4 & 4.9 & 1.1 & 4.2 \\
\hline \multicolumn{10}{|l|}{ Interaction } \\
\hline Simple & & - & - & 92.5 & 9.3 & 6.1 & 6.7 & - & - \\
\hline Complex & & - & - & 7.7 & 90.7 & 93.9 & 93.3 & - & - \\
\hline
\end{tabular}

CD - canopy diameter $(\mathrm{cm})$; PH - plant height $(\mathrm{cm})$; NFP - number of fruit per plant; MFM - mean fruit mass per plant (g); FL - fruit length (mm); DIAM - fruit diameter (mm); PTH - pulp thickness (mm); SSC - soluble solid

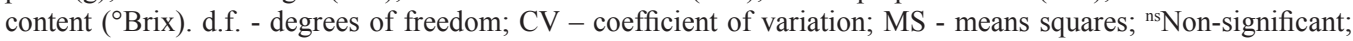
$*, * *=$ significant at 5 and $1 \%$ probability by the $\mathrm{F}$ test, respectively.

Seven of the eight traits showed significant differences in each assessed environment. This result may be due to environmental conditions, wherein Cáceres, MT, is characterized by the biome of "Pantanal" and Campos dos Goytacazes by the Atlantic Rain Forest. Significant differences were observed among all treatments $(\mathrm{P}<0.01)$ for all evaluated traits except for $\mathrm{CD}$ and $\mathrm{PH}$, whose significance was at $\mathrm{P}<0.05$ (Table 2). Thus, hybrids were genetically different, enabling selection of most promising genotypes to each condition.

GxE interaction was highly significant for NFP, MFM, FL, and DIAM. In contrast, there was no significant difference for CD, PH, PTH, and SSC (Table 2). Previous studies demonstrated significant GxE interactions in vegetables, mainly for quantitative traits (Moreira et al., 2009;

Genetics and Molecular Research 16 (2): gmr16029551 
Pimenta et al., 2016). In this study, the GxE interaction is explained not only by the quantitative nature of the traits but also because environments are different, as indicated by ANOVA combined analysis, in which environmental effects were the main contributors to the sum of total square. Therefore, testing in other locations would allow a better understanding of such interaction, interpreting results accurately without any negative interference on genotype selection.

The breakdown of GxE interaction into simple and complex parts showed a predominance of complex interactions for MFM, FL, and DIAM (Table 2). These results demonstrate that the evaluated hybrids had distinct responses to each local environmental condition (Cruz and Castoldi, 1991).

The Scott-Knott (Scott and Knott, 1974) cluster analysis grouped the hybrids into a single cluster for the variables PH and CD in both environments. Nevertheless, plants have grown best in Campos, since average plant height was $94.95 \mathrm{~cm}$, which corresponds to an increase of $17.73 \%$, compared to plants grown in Cáceres. In both environments, the hybrids were lower than the average of $104.78 \mathrm{~cm}$ obtained by Rêgo et al. (2011), who studied 40 accessions of C. baccatum. Regarding canopy diameter, hybrids presented an average of 98.5 $\mathrm{cm}$ in environment I and $116.0 \mathrm{~cm}$ in environment II, showing a more compact shape than the genotypes assessed by Rêgo et al. (2011) (Table 3). This trait has great relevance in this crop management, as most compact canopies facilitate cultural practices and enable a larger number of plants per area, which in turn may reflect in increased productivities (Bento et al., 2007; Rodrigues et al., 2012; Oliveira et al., 2015).

Table 3. Average eight agronomic traits in nine hybrids of Capsicum baccatum var. pendulum in two environments, Campos dos Goytacazes, RJ (E1) and Caceres, MT (E2) (Campos dos Goytacazes, Brazil).

\begin{tabular}{|c|c|c|c|c|c|c|c|c|}
\hline \multirow[t]{3}{*}{${ }^{1 /} \mathrm{H}$} & \multicolumn{8}{|c|}{ Agronomic traits } \\
\hline & \multicolumn{2}{|c|}{ PH } & \multicolumn{2}{|c|}{$\mathrm{CD}$} & \multicolumn{2}{|c|}{ NFP } & \multicolumn{2}{|c|}{ MFM } \\
\hline & E1 & E2 & E1 & E2 & E1 & E2 & E1 & E2 \\
\hline 1 & $89.6 \mathrm{a}$ & $81.3 \mathrm{a}$ & $88.57 \mathrm{a}$ & $121.14 \mathrm{a}$ & $393 c$ & $191 \mathrm{a}$ & $14.35 \mathrm{~d}$ & $6.65 \mathrm{~b}$ \\
\hline 2 & $99.8 \mathrm{a}$ & $91.7 \mathrm{a}$ & $107.55 \mathrm{a}$ & $122.70 \mathrm{a}$ & $890 \mathrm{a}$ & $290 \mathrm{a}$ & $11.70 \mathrm{~d}$ & $7.02 \mathrm{~b}$ \\
\hline 3 & $97.6 \mathrm{a}$ & $86.7 \mathrm{a}$ & $105.40 \mathrm{a}$ & $129.41 \mathrm{a}$ & $652 \mathrm{~b}$ & $177 \mathrm{a}$ & $19.08 \mathrm{c}$ & $11.48 \mathrm{a}$ \\
\hline 4 & $87.8 \mathrm{a}$ & $83.2 \mathrm{a}$ & $98.45 \mathrm{a}$ & $123.30 \mathrm{a}$ & $681 \mathrm{~b}$ & $206 \mathrm{a}$ & $11.78 \mathrm{~d}$ & $7.17 \mathrm{~b}$ \\
\hline 5 & $93.1 \mathrm{a}$ & $74.3 \mathrm{a}$ & $93.54 \mathrm{a}$ & $102.16 \mathrm{a}$ & $388 \mathrm{c}$ & $99 \mathrm{a}$ & $33.32 \mathrm{a}$ & $12.70 \mathrm{a}$ \\
\hline 6 & $87.4 \mathrm{a}$ & $67.5 \mathrm{a}$ & $90.74 a$ & $103.13 \mathrm{a}$ & $418 \mathrm{c}$ & $93 \mathrm{a}$ & $26.35 \mathrm{~b}$ & $10.95 \mathrm{a}$ \\
\hline 7 & $99.7 \mathrm{a}$ & $78.8 \mathrm{a}$ & $100.37 \mathrm{a}$ & $107.25 \mathrm{a}$ & $448 \mathrm{c}$ & $141 \mathrm{a}$ & $34.11 \mathrm{a}$ & $9.41 \mathrm{a}$ \\
\hline 8 & $98.9 \mathrm{a}$ & $86.3 \mathrm{a}$ & $99.61 \mathrm{a}$ & $119.97 \mathrm{a}$ & $560 \mathrm{c}$ & $185 \mathrm{a}$ & $24.32 \mathrm{~b}$ & $10.31 \mathrm{a}$ \\
\hline 9 & $100.7 \mathrm{a}$ & $79.4 \mathrm{a}$ & $102.27 \mathrm{a}$ & $115.00 \mathrm{a}$ & $634 \mathrm{~b}$ & $185 \mathrm{a}$ & $16.33 \mathrm{c}$ & $7.06 \mathrm{~b}$ \\
\hline \multirow{3}{*}{${ }^{1 /} \mathrm{H}$} & \multicolumn{8}{|c|}{ Agronomic traits } \\
\hline & \multicolumn{2}{|c|}{ FL } & \multicolumn{2}{|c|}{ DIAM } & \multicolumn{2}{|c|}{ PTH } & \multicolumn{2}{|c|}{ SSC } \\
\hline & E1 & E2 & E1 & E2 & E1 & E2 & E1 & E2 \\
\hline 1 & $91.73 \mathrm{c}$ & $69.32 \mathrm{a}$ & $23.24 \mathrm{f}$ & $18.14 \mathrm{~d}$ & $2.12 \mathrm{~b}$ & $2.33 \mathrm{~b}$ & $7.66 \mathrm{a}$ & $10.52 \mathrm{a}$ \\
\hline 2 & $72.12 \mathrm{~d}$ & $60.14 \mathrm{a}$ & $27.69 \mathrm{e}$ & $21.70 \mathrm{c}$ & $2.29 b$ & $2.51 \mathrm{~b}$ & $9.34 \mathrm{a}$ & $9.83 \mathrm{a}$ \\
\hline 3 & $50.13 \mathrm{e}$ & $38.94 \mathrm{~b}$ & $56.53 \mathrm{a}$ & $40.59 \mathrm{a}$ & $2.68 \mathrm{a}$ & $2.81 \mathrm{a}$ & $6.77 \mathrm{a}$ & $9.27 \mathrm{a}$ \\
\hline 4 & $71.05 \mathrm{~d}$ & $57.17 \mathrm{a}$ & $27.90 \mathrm{e}$ & $23.94 \mathrm{c}$ & $2.24 \mathrm{~b}$ & $2.39 \mathrm{~b}$ & $8.21 \mathrm{a}$ & $10.16 \mathrm{a}$ \\
\hline 5 & $98.77 \mathrm{c}$ & $65.51 \mathrm{a}$ & $42.28 \mathrm{~b}$ & $29.24 b$ & $2.85 \mathrm{a}$ & $2.93 \mathrm{a}$ & $7.99 \mathrm{a}$ & $9.86 \mathrm{a}$ \\
\hline 6 & $94.15 \mathrm{c}$ & $62.24 \mathrm{a}$ & $37.98 \mathrm{c}$ & $29.95 b$ & $2.69 \mathrm{a}$ & $2.72 \mathrm{a}$ & $7.33 \mathrm{a}$ & $9.58 \mathrm{a}$ \\
\hline 7 & $136.48 \mathrm{a}$ & $76.01 \mathrm{a}$ & $33.48 \mathrm{~d}$ & $21.81 \mathrm{c}$ & $2.33 \mathrm{~b}$ & $2.62 \mathrm{a}$ & $8.27 \mathrm{a}$ & $10.58 \mathrm{a}$ \\
\hline 8 & $74.36 \mathrm{~d}$ & $57.01 \mathrm{a}$ & $45.12 \mathrm{~b}$ & $29.08 \mathrm{~b}$ & $2.78 \mathrm{a}$ & $2.74 \mathrm{a}$ & $8.88 \mathrm{a}$ & $10.45 \mathrm{a}$ \\
\hline 9 & $110.66 \mathrm{~b}$ & $66.03 a$ & $26.08 \mathrm{e}$ & $18.96 \mathrm{~d}$ & $2.05 \mathrm{~b}$ & $2.21 \mathrm{~b}$ & $8.78 \mathrm{a}$ & $10.47 \mathrm{a}$ \\
\hline
\end{tabular}

${ }^{1 /} \mathrm{H}: \mathrm{H}_{1}=$ UENF 1616 x UENF 1624, $\mathrm{H}_{2}=$ UENF 1624 x 1639, $\mathrm{H}_{3}=$ UENF 1639 x 1732, $\mathrm{H}_{4}$ : UENF1624 x UENF 1732, $\mathrm{H}_{5}$ : UENF 1629 x UENF 1639, $\mathrm{H}_{6}$ : UENF 1629 x UENF 1732, $\mathrm{H}_{7}: 1616$ x UENF $1629, \mathrm{H}_{8}$ : UENF $1616 \mathrm{x}$ UENF 1639, $\mathrm{H}_{9}$ : UENF 1624 x UENF 1629. PH - plant height $(\mathrm{cm})$; CD - canopy diameter $(\mathrm{cm})$; NFP - number of fruit per plant; MFM - mean fruit mass per plant (g); FL - fruit length (mm); DIAM - fruit diameter (mm); PTH - pulp thickness (mm); SSC - soluble solid content ( ${ }^{\circ}$ Brix). The means followed by the same letter do not differ by the Scott-Knott clustering test $(\mathrm{P} \leq 0.05)$.

Genetics and Molecular Research 16 (2): gmr16029551 
Regarding the NFP in environment I, there was a variation of 388 and 890 harvested fruit from hybrids 5 and 2, respectively. This gap provided the formation of three distinct groups. In environment II, all hybrids were allocated into a single group by the Scott-Knott test (1974), so there was no difference among them. For MFM, four groups were formed, being two of them in environment I, with values varying from 11.7 to $34.11 \mathrm{~g}$; and another two groups in environment II, whose means were from 6.65 to $12.70 \mathrm{~g}$ (Table 3).

With respect to fruit shape (FL and DIAM), hybrids presented a variation among them. In environment I, FL ranged from 50.13 to $136.48 \mathrm{~mm}$, and in environment II, this range was from 38.94 to $76.01 \mathrm{~mm}$. For DIAM measurements, there was a variation of 23.24 to $56.53 \mathrm{~mm}$ in environment I, and of 18.14 to $40.59 \mathrm{~mm}$ in environment II (Table 3).

The formation of different groups for NFP, MFM, FL, and DF was expected due to the varied fruit shapes of parents of the hybrids. It suggests that hybrids must be appraised concerning their value for cultivation and use, assessing them by groups of similar fruit formats. The genotypes whose fruits have characteristic shape of "dedo-de-moça" (long and thin) will be compared among them, and genotypes with "cambuci" shape (short and thick) will be evaluated separately. This will facilitate the identification of promising genotypes within each group. This variation among hybrid groups is important to meet diverse consumer market demands (Lin et al., 2013). The shape and size are important traits when purchasing for Capsicum fruits, varying with consumer's age (Onoyama et al., 2010; Paulus et al., 2015).

PTH has direct influence on mass and post-harvest conservation of Capsicum fruit, i.e., is linked to fruit yield and quality (Blat et al., 2007). For such trait, hybrids were differentiated into two groups in both environments. In environment I, hybrids 3, 5, 6, and 8 formed the thick pulp group with an average of $2.75 \mathrm{~mm}$. Similarly, in environment II, the same hybrids plus 7 had the highest average $(2.76 \mathrm{~mm})$ for this trait (Table 3$)$. These values are higher than the average value of $2.1 \mathrm{~mm}$ obtained by Rêgo et al. (2009), who studied $56 \mathrm{~F}_{1}$ hybrids derived from diallelic crosses among eight parents of C. baccatum.

With respect to the content of SSC, which is directly related to fruit flavor, hybrids were allocated into a single group, showing averages of 8.14 and $10.08^{\circ}$ Brix for environment I and II, respectively (Table 3 ). These values are consistent with those observed in the literature, such as $9.28^{\circ}$ Brix (Rodrigues et al., 2012) and $10.02^{\circ}$ Brix (Oliveira et al., 2015). Interestingly, studies have pointed out that there is a negative correlation between SSC and productivity (Rêgo et al., 2011). Once the values found here are according to data found in the literature and do not differ significantly, it can be said that there will be no quality loss when selecting the most productive hybrids.

The evaluated hybrids yield around 5 and $11 \mathrm{t} / \mathrm{ha}$, with a productive potential of $20 \mathrm{t} /$ ha under suitable harvesting conditions and two of their parents resistant to PepYMV (Bento et al., 2009; Medeiros et al., 2014).

The ratio between genetic variation coefficient and environmental variation coefficient was above unity for most of the traits (NFP, MFM, FL, DIAM, PTH, and SSC). In addition, high values of genotypic determination coefficient were observed (Table 4). Such situation is desired, since it indicates that phenotypic expression had a major contribution from genetics (Nick et al., 2013).

Multivariate analysis allowed the grouping of hybrids based on the traits NFP, MFM, FL, and DIAM. These characteristics were significantly influenced by the GxE interaction and might have effect on fruit shape. Hybrids were divided into three groups in the environment I and four groups in the environment II. By comparing the dendrograms, we noticed partial

Genetics and Molecular Research 16 (2): gmr16029551 
coincidence in group formation of both environments. The hybrid 3 stood out from the others in both environments, since it reached the highest yield and fruit diameter besides of shortest fruit length. This highlight is consistent since that is the only hybrid with bell-shaped fruit whose parents produce fruit in the same format. Another coincident group was composed of the hybrids 5, 6, and 8, which had the second lowest ratio between fruit length and diameter. This can be explained because all hybrids have seed-bearing parental line with lengthened fruit and a pollen-bearing line with bell-shaped ones. The other groups were not identical, supporting the differential response of hybrids to each environment (Figure 1).

Table 4. Estimates of genetic variation coefficient $\left(\mathrm{CV}_{\mathrm{g}}\right)$ and environmental variation coefficient $\left(\mathrm{CV}_{\mathrm{e}}\right)$ on eight quantitative traits related to plant and fruit of hybrids of Capsicum baccatum var. pendulum in two environments, Campos dos Goytacazes, RJ, and Caceres, MT (Campos dos Goytacazes, Brazil).

\begin{tabular}{l|c|c|c|c|c|c|c|c}
\hline & CD & PH & NFP & MFM & FL & DIAM & PTH & SSC \\
\hline $\mathrm{CVg}$ & 5.30 & 4.89 & 28.71 & 34.16 & 23.10 & 28.76 & 10.12 & 5.29 \\
\hline $\mathrm{CVg} / \mathrm{CVe}$ & 0.56 & 0.51 & 1.32 & 2.94 & 3.31 & 5.24 & 1.29 & 73.71 \\
\hline $\mathrm{H}^{2}$ & 65.40 & 61.50 & 91.28 & 98.11 & 98.5 & 99.39 & 90.95 & 0.68 \\
\hline
\end{tabular}

CD - canopy diameter; PH - plant height; NFP - number of fruit per plant; MFM - mean fruit mass per plant; FL fruit length; DIAM - fruit diameter; PTH - pulp thickness; SSC - soluble solids content.

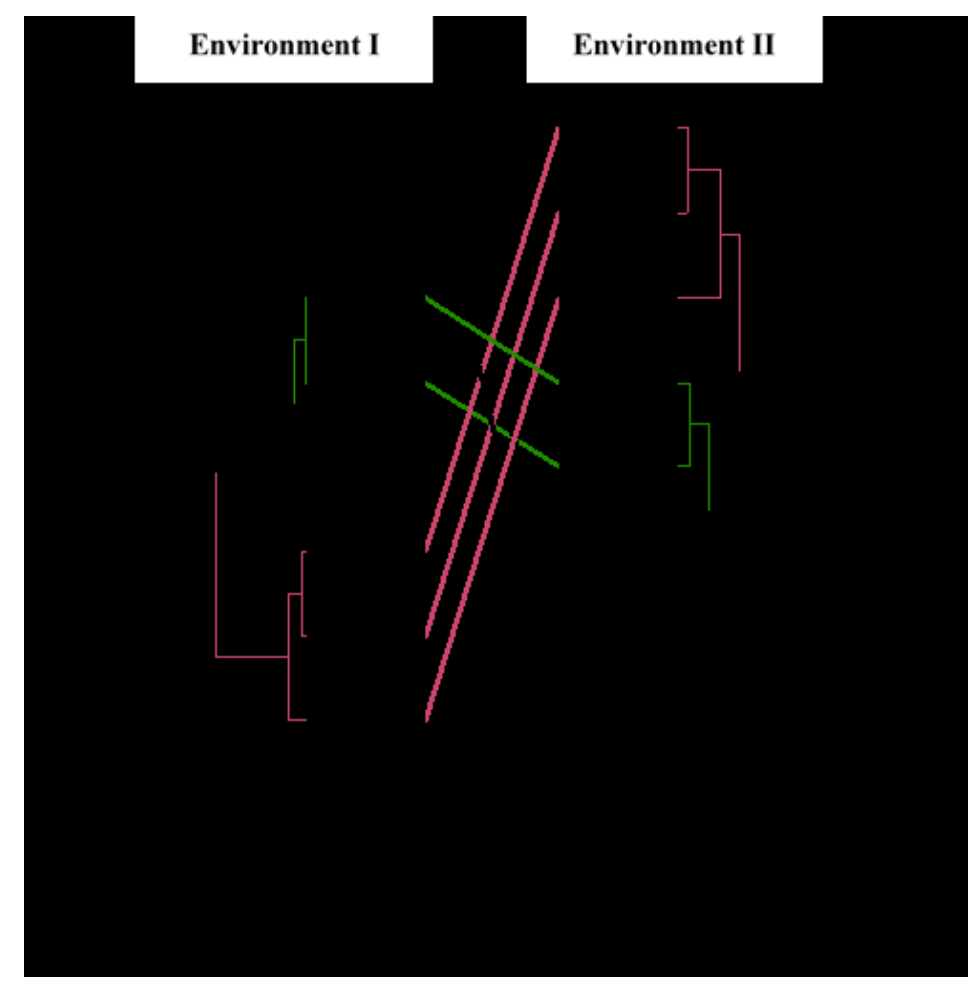

Figure 1. Dendrogram of genetic dissimilarity between 30 genotypes of Capsicum baccatum var. pendulum obtained by UPGMA based on the dissimilarity matrix of morphological and agronomic descriptors (Campos dos Goytacazes, Brazil). 
One hybrid should be chosen to each environment based on the desired traits, once there were simple and complex interactions for most of the studied traits. Furthermore, we recommend that these hybrids be tested in other environments, verifying thus their adaptability and stability in a wider range of environmental conditions, enabling a most accurate indication of $C$. baccatum hybrids according to each region.

\section{Conflicts of interest}

The authors declare no conflict of interest.

\section{REFERENCES}

Bento CS, Sudré CP, Rodrigues R, Riva EM, et al. (2007). Descritores qualitativos e multicategóricos na estimativa da variabilidade fenotípica entre acessos de pimentas. Sci. Agric. 8: 149-156.

Bento CS, Rodrigues R, Zerbini Júnior FM and Sudré CP (2009). Sources of resistance against the Pepper yellow mosaic virus in chili pepper. Horticult. Bras. 27: 196-201.

Bento CS, Rodrigues R, Gonçalves LSA, Oliveira HS, et al. (2013). Inheritance of resistance to Pepper yellow mosaic virus in Capsicum baccatum var. pendulum. Genet. Mol. Res. 12: 1074-1082. http://dx.doi.org/10.4238/2013.April.10.3

Bhutia ND, Seth T, Shende VD, Dutta S, et al. (2015). Estimation of heterosis, dominance effect and genetic control of fresh fruit yield, quality and leaf curl disease severity traits of chilli pepper (Capsicum annuиm L.). Sci. Hortic. (Amsterdam) 182: 47-55. http://dx.doi.org/10.1016/j.scienta.2014.11.017

Blat SF, Braz LT and Arruda AS (2007). Avaliação de híbridos duplos de pimentão. Hortic. Bras. 25: 350-354. http:// dx.doi.org/10.1590/S0102-05362007000300006

Butcher JD, Crosby KM, Yoo KS, Patil B, et al. (2013). Heterosis in different F Capsicum annuum genotypes for fruit traits, ascorbic acid, capsaicin, and flavonoids. Sci. Hortic. (Amsterdam) 159: 72-79. http://dx.doi.org/10.1016/j. scienta.2013.03.022

Carvalho SIC, Ribeiro CSC, Henz GP and Reifschneider FJB (2009). 'BRS Mari': new hot pepper cultivar for processing. Hortic. Bras. 27: 571-573. http://dx.doi.org/10.1590/S0102-05362009000400028

Charlo HCO, Galatti FS, Braz LT and Barbosa JC (2011). Híbridos experimentais de melão rendilhado cultivados em solo e substrato. Rev. Bras. Frutic. 33: 144-156. http://dx.doi.org/10.1590/S0100-29452011005000028

Cruz CD (2013). GENES - a software package for analysis in experimental statistics and quantitative genetics. Acta Scientiarum 35: 271-276.

Cruz CD and Castoldi FL (1991). Decomposição da interação genótipos x ambientes em partes simples e complexa. Rev. Ceres 8: 422-430.

Cruz CD, Regazzi AJ and Carneiro PCS (2012). Modelos biométricos aplicados ao melhoramento Genético. 2nd edn. UFV, Viçosa.

Filgueira FAR (2012). Novo manual de olericultura: agrotecnologia moderna na produção e comercialização de hortaliças. 3nd edn. UFV, Viçosa.

Gonçalves LSA, Rodrigues R, Bento CS, Robaina RR, et al. (2011). Herança de caracteres relacionados à produção de frutos em Capsicum baccatum var. pendulum com base em análise dialélica de Hayman. Cienc. Agron. 42: 662-669. http://dx.doi.org/10.1590/S1806-66902011000300012

Leite PSS, Rodrigues R, Silva RNO, Pimenta S, et al. (2016). Molecular and agronomic analysis of intraspecific variability in Capsicum baccatum var. pendulum accessions. Genet. Mol. Res. 15: 1504-1521. http://dx.doi.org/10.4238/ gmr.15048482

Lin S, Chou Y, Shieh H, Ebert AW, et al. (2013). Pepper (Capsicum spp.) Germplasm Dissemination by AVRDC - The World Vegetable Center: an Overview and Introspection. Chron. Hortic. 53: 21-27.

Madail JCM, Schneid LF, Sima LF and Wendt AN (2005). Economia da produção de pimenta vermelha no município de Turuçu-RS. Embrapa Clima Temperado (Boletim de Pesquisa e Desenvolvimento), 19, Pelotas.

Medeiros AM, Rodrigues R, Gonçalves LSA, Sudré CP, et al. (2014). Gene effect and heterosis in Capsicum bacacatum var. pendulum. Cienc. Rural 44: 1031-1036. http://dx.doi.org/10.1590/S0103-84782014000600013

Moreira SO, Rodrigues R, Araújo ML, Sudré CP, et al. (2009). Desempenho agronômico de linhas endogâmicas recombinadas de pimenta em dois sistemas de cultivo. Cienc. Rural 39: 1387-1393. http://dx.doi.org/10.1590/S0103$\underline{84782009005000080}$

Genetics and Molecular Research 16 (2): gmr16029551 
Moulin MM, Rodrigues R, Bento CS, Gonçalves LS, et al. (2015a). Genetic dissection of agronomic traits in Capsicum baccatum var. pendulum. Genet. Mol. Res. 14: 2122-2132. http://dx.doi.org/10.4238/2015.March.20.23

Moulin MM, Rodrigues R, Ramos HCC, Bento CS, et al. (2015b). Construction of an integrated genetic map for Capsicum baccatum L. Genet. Mol. Res. 14: 6683-6694. http://dx.doi.org/10.4238/2015.June.18.12

Nascimento IR, Maluf WR, Faria MV, Valle LAC, et al. (2004). Capacidade combinatória e ação gênica na expressão de caracteres de importância econômica em pimentão. Cienc. Agrotec. 28: 251-260. http://dx.doi.org/10.1590/S141370542004000200002

Nick C, Laurindo BS, Almeida VS, Freitas RD, et al. (2013). Seleção simultânea para qualidade do fruto e resistência à requeima em progênies de tomateiro. Pesqui. Agropecu. Bras. 48: 59-65. http://dx.doi.org/10.1590/S0100204X2013000100008

Oliveira HS, Rodrigues R, Bento CS, Medeiros AM, et al. (2015). Towards a new strategy to breed an autogamous plant: A case of study in Capsicum baccatum var. pendulum. Sci. Hortic. (Amsterdam) 192: 279-286. http://dx.doi. org/10.1016/j.scienta.2015.06.017

Onoyama SS, Reifschneider FJB, Moita AW and Souza GS (2010). Atributos de hortaliças sob a ótica de consumidores: estudo de caso do pimentão no Distrito Federal. Hortic. Bras. 28: 124-132. http://dx.doi.org/10.1590/S0102$\underline{05362010000100024}$

Paulus D, Valmorbida R, Santin A, Toffoli E, et al. (2015). Crescimento, produção e qualidade de frutos de pimenta (Capsicum аппиит) em diferentes espaçamentos. Hortic. Bras. 33: 91-100. http://dx.doi.org/10.1590/S0102$\underline{053620150000100001}$

Pimenta S, Menezes D, Neder DG, Melo RA, et al. (2016). Adaptability and stability of pepper hybrids under conventional and organic production systems. Hortic. Bras. 34: 168-174. http://dx.doi.org/10.1590/S0102-053620160000200004

Ramalho MAP, Abreu AFB, Santos JB and Nunes JAR (2012). Aplicações da genética quantitativa no melhoramento de plantas autógamas. 1st edn. Editora UFLA, Lavras.

Rêgo ER, Rêgo MM, Finger FL, Cruz CD, et al. (2009). A diallel study of yield components and fruit quality in chilli pepper (Capsicum baccatum). Euphytica 168: 275-287. http://dx.doi.org/10.1007/s10681-009-9947-y

Rêgo ER, Rêgo MM, Cruz CD, Finger FL, et al. (2011). Phenotypic diversity, correlation and importance of variables for fruit quality and yield traits in Brazilian peppers (Capsicum baccatum). Genet. Resour. Crop Evol. 58: 909-918. http://dx.doi.org/10.1007/s10722-010-9628-7

Rêgo MM, Sapucay MJLC, Rêgo ER and Araújo ER (2015). Analysis of divergence and correlation of quantitative traits in ornamental pepper(Capsicum spp.). Acta Hortic. 1087:389-394. http://dx.doi.org/10.17660/ActaHortic.2015.1087.52

Rodrigues R, Gonçalves LSA, Bento CS, Sudré CP, et al. (2012). Capacidade combinatória e heterose para características agronômicas em pimentas do complexo baccatum. Hortic. Bras. 30: 226-233. http://dx.doi.org/10.1590/S0102$\underline{05362012000200008}$

Scott AJ and Knott M (1974). A cluster analysis method for grouping means in the analysis of variance. Biometrics 30 : 507-512. http://dx.doi.org/10.2307/2529204

Silva AR, Cecon PR, Rêgo ER and Nascimento M (2011). Avaliação do coeficiente de variação experimental para caracteres de frutos de pimenteiras. Rev. Ceres 58: 168-171. http://dx.doi.org/10.1590/S0034-737X2011000200006

Singh P, Cheema DS, Dhaliwa MS and Garg N (2014). Heterosis and combining ability for earliness, plant growth, yield and fruit attributes in hot pepper (Capsicum annuит L.) involving genetic and cytoplasmic-genetic male sterile lines. Sci. Hortic. (Amsterdam) 168: 175-188. http://dx.doi.org/10.1016/j.scienta.2013.12.031 